International Journal of Agriculture, Environment and Bioresearch

Vol. 5, No. 04; 2020

ISSN: $2456-8643$

\title{
JUMPING PLANT-LOUSE EURYCONUS DIALIA SP. NOV. (HEMIPTERA: PSYLLIDAE), ASSOCIATED WITH DIALIUM SP. (FABACEAE) IN CAMEROON
}

\author{
Yana Wenceslas ${ }^{1,2^{*}}$, Dzokou Victor Joly ${ }^{2,3}$, Mveyo Ndankeu Yves Patrick ${ }^{2,4}$ and Tamesse Joseph Lebel ${ }^{2}$ \\ ${ }^{1}$ Laboratory of Biological Sciences, Faculty of Sciences, University of Bamenda, P.O. Box 39 Bambili, Cameroon \\ ${ }^{2}$ Laboratory of Zoology, Higher Teacher's Training College, University of Yaounde I, P.O. Box 47 Yaounde, \\ Cameroon \\ ${ }^{3}$ Laboratory of Agricultural Zoology, Department of Plant Protection, Faculty of Agronomy and Agricultural \\ Sciences, University of Dschang, Cameroon \\ ${ }^{4}$ Laboratory of Zoology, Faculty of Sciences, University of Yaounde I, P.O. Box 812 Yaounde, Cameroon
}

https://doi.org/10.35410/IJAEB.2020.5542

\begin{abstract}
Jumping plant lice are phytophagous insects which induce damages to their host plants. The biodiversity of Cameroonian psyllid fauna is important but many species remain unknown. Euryconus dialia sp. nov. is associated with Dialium sp. a valuable timber tree in which the psyllid induces necrosis of leaves especially young plants. The aim of this work is the describe and identify the psyllid associated with Dialium sp. in Cameroon, a contribution of the psyllid biodiversity study in Cameroonian fauna. From the description E. dialia sp. nov. is characterized by forewing pattern in which the surface is covered by large brown band which is darker on the distal portion of the wing and on c+sc cell, a light white area covered the third surface of $\mathrm{c}+\mathrm{sc}$ cell on the proximal portion and another light white area is surrounding half of the Rs vein; internal veins carrying dark patches except $\mathrm{M} 2+3$ and $\mathrm{R}+\mathrm{M}+\mathrm{Cu}$ veins. Genal processes well developed and broad anteriorly slightly incised forming two tubercles on the apex. Terminal abdominal margin with 4+4 truncate sectasetae; anus oval, in terminal position; circumanal ring consisting of a single row of pores; additional pore fields developed, convulted, extending much onto abdominal dorsum and consisting of a single row of wax pores. Comparing E. dialia with the specimens recorded previously elsewhere it is morphologically different from them and can be reported as new species in the Euryconus genus.
\end{abstract}

Keywords: Taxonomy, Euryconus, psyllid, Baphiopsis parvifolia, Cameroon.

\section{INTRODUCTION}

The plants are associated with good number of insect species to provide to them nutritive elements for their surviving; among those insects psyllids are included. Psyllids generally called jumping plant-lice, are plant sap sucking insects belonging to Hemiptera order principally associated to perennial dicotyledone plants [1,2,3,4,5]. Psyllids induce several types of damages to their host plants: necrosis of some parts of the host plant, formation of galls, stunting of buds and leaves; some species are vectors and transmit pathogens to their host plant when they are feeding. The diseases transmitted by the psyllids induced the degeneration of the host plants. 
Vol. 5, No. 04; 2020

ISSN: $2456-8643$

According to [6], the larvae induce severe damages to the host plants while adults transmitted disease to host plants. They attack mostly soft tissues of the host plants, young plants, and shoots of host plants. Psyllid developmental cycle consist of: egg, five larval stages and adult. The psyllid life span depends of host plant phenology, climatic factors, and natural enemies [7,8]. To control the psyllids pest of plants is necessary to identify them and many psyllid species remain unknown in the world. Nowadays there are around 4000 described psyllid species in the world and most of them were recorded in temperate and sub-tropical regions of the world [9]. Afrotropical psyllid fauna is less known when it considered having important diversity of those insects because the plants biodiversity in afrotropical region is very important. So far, psyllid species have been recorded in Cameroon and few of them have been described by some authors such as [10,11,12,13] described 3 species: Pseudoeriopsylla genus and Trioza messii; [14] described Diclidophlebia andjigae; $[15,16,17,18]$ described 2 species in Trioza genus, 2 species in Paurocephala genus and 6 species in Carsidaridae family; [19,20,21] described 3 species: Pseudophacopteron burckhardti, Phytolyma tchuentei, and Blastopsylla occidentalis; [22] described 9 species in Pseudophacopteron genus; [23] described 5 species in Diclidophlebia genus; [24] described 14 species in Triozidae family. Many psyllid species remain not described and for now there is no described species in Eryconus genus in Cameroon. The main objective of this work is to describe and identify the psyllid of Dialium sp. a contribution for the study of biodiversity of psyllids in Cameroonian fauna.

\section{MATERIALS AND METHODS}

The specimens described in this work were collected in Kala and Nkomilong localities of in Mbankomo Sub-division, Mefou Akono Division, Centre Region of Cameroon. The geogra phical coordinates were specimens were sampled are: mountain Kala; latitude: $03^{\circ} 50^{\prime} 121^{\prime}$ 'N, longitude: $11^{\circ} 26^{\prime} 004^{\prime \prime} \mathrm{E}$, altitude: $1122 \mathrm{~m}$ and mountain Nkomilong; latitude: $03^{\circ} 49^{\prime} 954^{\prime} \mathrm{N}$, longitude: $11^{\circ} 20^{\prime} 504^{\prime \prime} \mathrm{E}$, altitude: $1161 \mathrm{~m}$. On the field adult psyllids were captured with entomological sweep net of $0.5 \mathrm{~mm}$ mesh size and mouth aspirator. Larvae were sampled directly from buds and leaves of the host plant with soft brush. The specimens were preserved in $70 \%$ ethanol and were deposited in Laboratory of Zoology, Higher Teacher's Training College, University of Yaounde I (LZUY), and Naturhistorisches Museum Basel, Switzerland (NHMB). The host plant was identified by Professor Bonaventure Sonké of the University of Yaounde I. The measurements of adults were done with the use of a stereomicroscope (mark LEICA L2) having an ocular micrometer graduated from 0 to 10 micrometric units. Measurements done on the adults were body length; body width; head width; antenna length; first flagellomere length; genal process length; forewing length; forewing width; hindwing length; hindwing width; metatibia length; metafemur length; male proctiger length; paramere length; distal segment of aedeagus length; female proctiger length; female subgenital plate length. Measurements of the $5^{\text {th }}$ instar immature, were: body length; body width; antenna length; forewing-pad length; metatibia length. The adult specimens were maintained in a solution of sodium hydroxide $(\mathrm{KOH})$ at $10 \%$ for about 4 hours. This solution dissolved the internal organs and softened the chitinous cuticle. The different organs to describe in adults were detached with the help of two fine needles mounted on wooden handles. The mounting was done under the stereomicroscope. The dissected organs were mounted on an objective slide in polyvinyl drop and covered with an objective slide cover. The mounted slides are dried using light bulb. The illustrations were realized under a 
microscope equipped with a drawing tube mark LEICA DM. 1000. SPSS version 16.0 program was used for statistical analysis. The morphological terminology follows mostly [25,26,27].

\section{RESULTS}

Fifth instar immature

Colouration: overall body yellowish, half of the distal portion of abdomen completely yellow brown, anterior part of abdomen with four brown bands; dorsal face of thorax with 4 brown spots dorsal part of head covered totally by brown patch; wing pads brown and eyes redish.

Structure: fifth instar immature dorsoventrally flattened (fig.1); head with $3+3$ simple setae. Antenna relatively long with ten segments, flagellum with a single rhinarium on the flagellomere 2, 4, 6 and 8. Wing pads sparse of short setae. The mesotibia with single capitate seta; metabasitarsus also with single capitate seta, metatibia with 3 regularly spaced apical spurs on external face and 2 on internal face, metabasitarsus with 2 single apical spur (fig.2). Terminal abdominal margin with $4+4$ truncate sectasetae; anus oval, in terminal position; circumanal ring consisting of a single row of pores; additional pore fields developed, convulted, extending much onto abdominal dorsum and consisting of a single row of wax pores (fig.3). Measurements found in table 1 .

Adult

Colouration: the overall body brown in male; and yellowish in female but the thorax is slightly darker than abdomen; in male abdominal sclerites brown separated by yellowish intersegmental membrane. Eyes dark reddish grey, ocelli lighter whitish. Antenna brownish but flagellomeres 5 and 6 with dark tip; fagellomeres 9 and 10 completely dark. Forewing surface covered by large brown band which is darker on the distal portion of the wing and on $c+s c$ cell, a light white area covered the third surface of $c+s c$ cell on the proximal portion and another light white area surrounding half of the Rs vein. All the internal veins of the forewing carrying dark patches except $\mathrm{M}_{2+3}$ and $\mathrm{R}+\mathrm{M}+\mathrm{Cu}$ veins; black pteriostigma. Hindwing hyaline with brown veins. Metatibia and metabasitarsus with black spurs.

Structure: head strongly inclined from longitudinal body axis resulting in an arched dorsal outline of the thorax and wider than pronotum; vertex trapezoidal, 1.8 times as wide as long, covered by inconspicuous short setae; genal processes well developed and broad anteriorly slightly incised forming two tubercles on the apex, genal process 1.2 times as wide as long, each genal process carrying 7 long simple setae and inconspicuous short setae (fig.4). Antenna relatively long 1.04-1.15 times as long as head width, fifth flagellomere the longest, single simple subapical rhinarium on flagellomeres 2, 4, 6 and 7, terminal setae long and flagellomere 2, 5, and 6 each with two setae while flagellomere 3, 4, and 7 each with single seta (fig.5). The pronotum of the prothorax and mesonotum of mesothorax less large than the head wide; mesonotum slightly arched while metanotum relatively large. The hind leg with long coxa carrying short and pointed meracanthus; metatibia without conspicuous genual spine, metatibia with 4 regularly spaced apical spurs on internal face and 3 on external face; metabasitarsus with 2 regularly spaced apical spurs; and hind leg ending by an arolium composed of two lobes (fig.6,7). Forewing (fig.8) elongate rounded apically, 2.0-2.1 times as long as wide, 2.5-2.6 times as long as head width; pterostigma long and triangular with broad base and narrow end; covered the 3/4 of Rs vein length; $\mathrm{M}_{1+2}$ vein 1.3 times longer than $\mathrm{M}_{3+4}$ vein while $\mathrm{Cu}_{1 \mathrm{a}}$ vein 2.3 times 
longer than $\mathrm{Cu}_{1 \mathrm{~b}}$ vein; dorsal surface of veins with short hairs; $c u_{1}$ cell 0.8 times higher than wide. Hindwing (fig.9) with 2 setae before the costal break and 5 evenly spaced setae after the costal break; vein $\mathrm{R}+\mathrm{M}+\mathrm{Cu}$ splitting into $\mathrm{R}$ and $\mathrm{M}+\mathrm{Cu}$, vein $\mathrm{M}+\mathrm{Cu}$ splitting into $\mathrm{M}$ and $\mathrm{Cu}$, vein $\mathrm{Cu}$ splitting into $\mathrm{Cu}_{1 \mathrm{a}}$ and $\mathrm{Cu}_{1 \mathrm{~b}}$.. Male terminalia (fig.10) proctiger unipartite and tubular; male subgenital plate trapezoidal. Paramere (fig.11) relatively long with broad proximal part and incurved internal margin ending by a sclerotinised hooked pointed apex, paramere sparsely covered with long simple setae. Distal segment of aedeagus relatively long, strongly inflated apically or distal dilatation irregularly oval with truncate apex and sclerotised end tube of ductus ejaculatorius relatively long and thick (fig.12). Female terminalia (fig.13) relatively long with broad proximal part and tapering apical half ending by rounded apex; circumanal ring elongate narrow and incurved consisting of two rows of elongate wax pores; subgenital plate triangular with broad proximal part and rounded apex; ovipositor well developed; valvula lateralis bluntly rounded apically; valvulae dorsalis and ventralis long and straight. Measurements found on table 2.

Etymology: the species name refers to its host plant name Dialium sp.

Material examined: Holotype $\widehat{\sigma}$, Cameroon, Centre Region; mountain Kala, latitude:

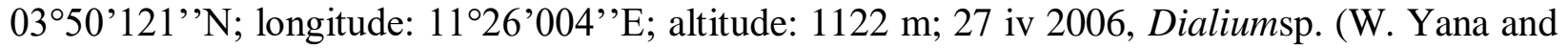
J.L. Tamesse); mounted slides (LZUY).

Paratypes. Cameroon: mountain Kala: 8ภ̂, 14ㅇ, 3 larvae, 27 iv 2006 same collection with

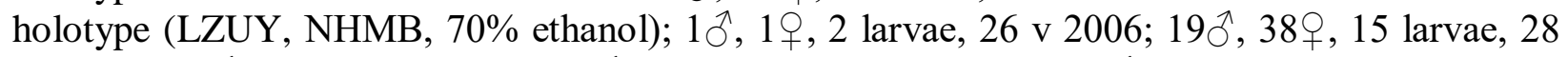
vii 2006; $15 \hat{\jmath}, 25$, 28 viii 2006; $3 \hat{\jmath}, 2$, 12 larvae, 27 xi 2006; $8 \hat{\jmath}, 9$,, 2 larvae, 16 ii 2007;

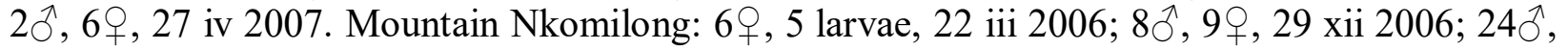

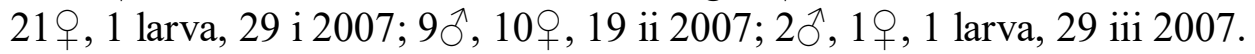

Bio-ecology and damage: the adults and larvae of Euryconus dialia (fig.14,a,b,c) are sucking sap of the host. Adults feed on the veins of the leaves while the immature stages feed on the host plant buds and produce white wax filaments. The highest number of adults and larvae was observed from June to September when there is moderated rainfall and from December to March during dry season. Numerical variation of $E$. dialia individuals in the year depends of the phenology of the host plant. The remarkable damage the psyllid induces to its host plant is the necrosis of the leaves especially when the host plant is young (fig.14d).

\section{DISCUSSION}

According to [28], the genus Euryconus is more related with the genera such as Brinckitia [29] with type-species Brinckitia annosa [29]; Colophorina [26] with type-species Colophorina cassiae [26]; Epiacizzia [30] with type-species Epiacizzia edentalis [30]; Euphaleropsis [31] with type-species: Euphaleropsis drypetis [31]; Euphalerus [32] with type-species Euphalerus nidifex [32]; Euryconus [33] with type-species Euryconus enderleini [33]; Macrocorsa [34] with type-species: Macrocorsa congensis [34]; Paraphyllura [35] with type-species Paraphyllura micheliae [35]; Peregrinivena [36] with type-species Peregrinivena liangheana [36]; Pugionipsylla [37] with type-species: Pugionipsylla lysidice [37]; Retroacizzia [29] with typespecies Arytaina mopani [38]; Tridencopsylla [30] with type-species: Psylla hungtouensis [39]. 
According to [40] Macrocorsa genus resemble more to Colophorina and Euryconus genera. The forewing of the three genera is rhomboidal, pattern consisting of dark spots or patches, absence of genual spine on metatibia. Euryconus genus differs from Colophorina and Macrocorsa genera in that the head in profile, inclined from longitudinal body axis in an angle of about $0-45^{\circ}$; number of apical metatibia spurs 6-8; fifth instar immature with Capitate setae and anus is ventral.

Euryconus dialia differs from Euryconus sp. recorded by [25] in Brazil the fact that the forewing pattern is composed of surface covered by large brown band darker on the distal portion of the wing and on $c+s c$ cell, a light white area covered the third surface of $c+s c$ cell on the proximal portion and another light white area surrounding half of the Rs vein. All the internal veins of the forewing carrying dark patches except $\mathrm{M}_{2+3}$ and $\mathrm{R}+\mathrm{M}+\mathrm{Cu}$ veins while in Euryconus sp. the forewing pattern without large brown band and bearing several brown spots on the veins and cells. In Euryconus dialia genal processes well developed and broad anteriorly slightly incised forming two tubercles on the apex, while in Euryconus sp. genal processes well developed and deeply incised forming two tubercles.

\section{CONCLUSION}

Euryconus dialia sp. nov. described in this work is morphologically different from the other species recorded previously elsewhere. The morphological characters specific for $E$. dialia are based on the forewing pattern, genal processes, and the circumanal of the fifth instar immature. Considering the economic importance of the host pant Dialium sp. (Fabaceae), is urgent put in place appropriate control method to fight against the pest insect described in this work.

\section{Acknowledgements}

We thank Pr. Daniel Burckhardt of the Naturhistorisches Museum of Basel in Switzerland for the preliminary identification of the specimens. 
Vol. 5, No. 04; 2020

ISSN: $2456-8643$
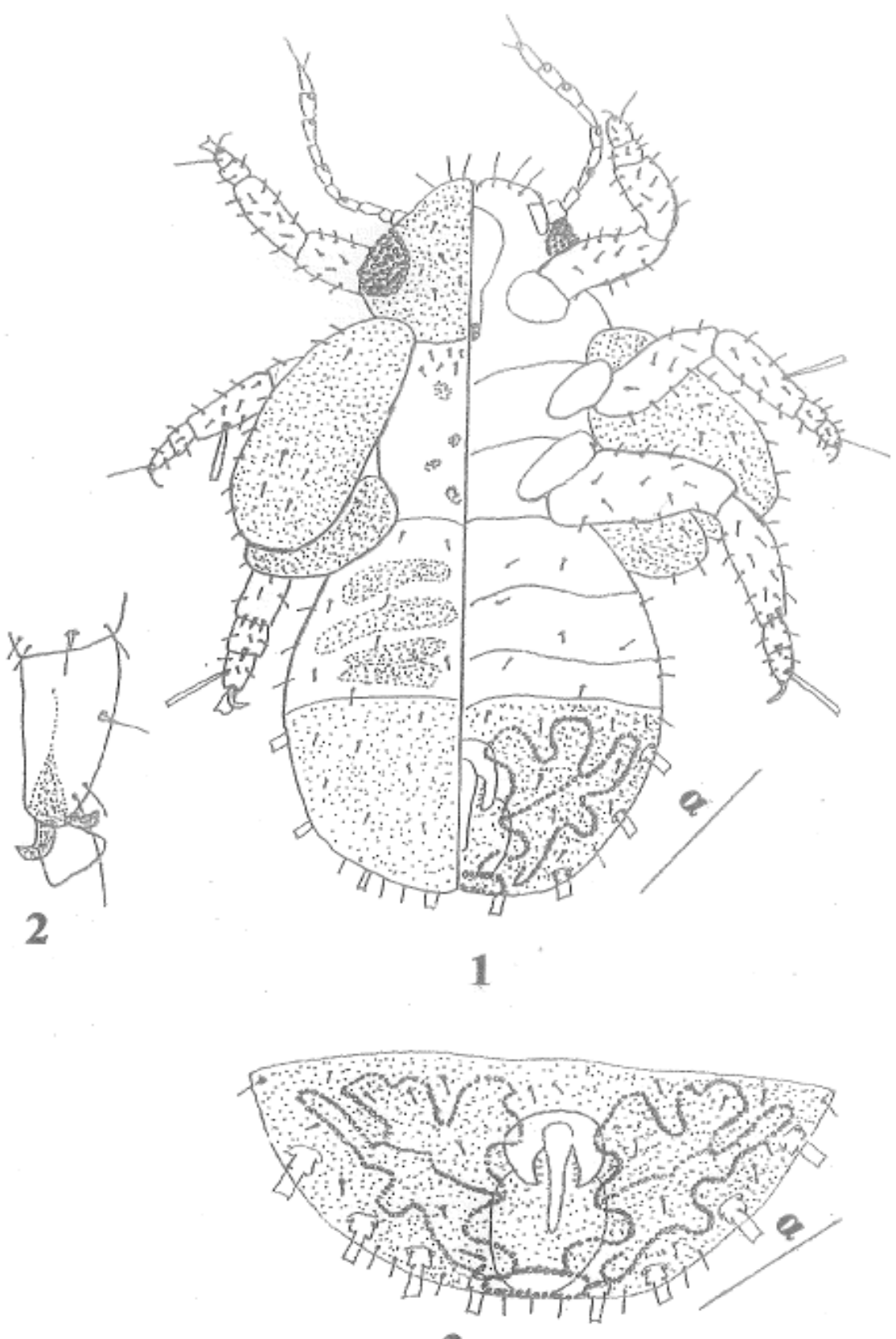

3

Figures 1-3: Euryconus dialia sp. nov.: 1, fifth instar larva, dorsal view (right), ventral view (left); 2, tarsal apex with claws and arolium; 3, ventral view of larval apical abdomen. Scale bars: $\alpha=0.24 \mathrm{~mm}$. 
Vol. 5, No. 04; 2020

ISSN: $2456-8643$

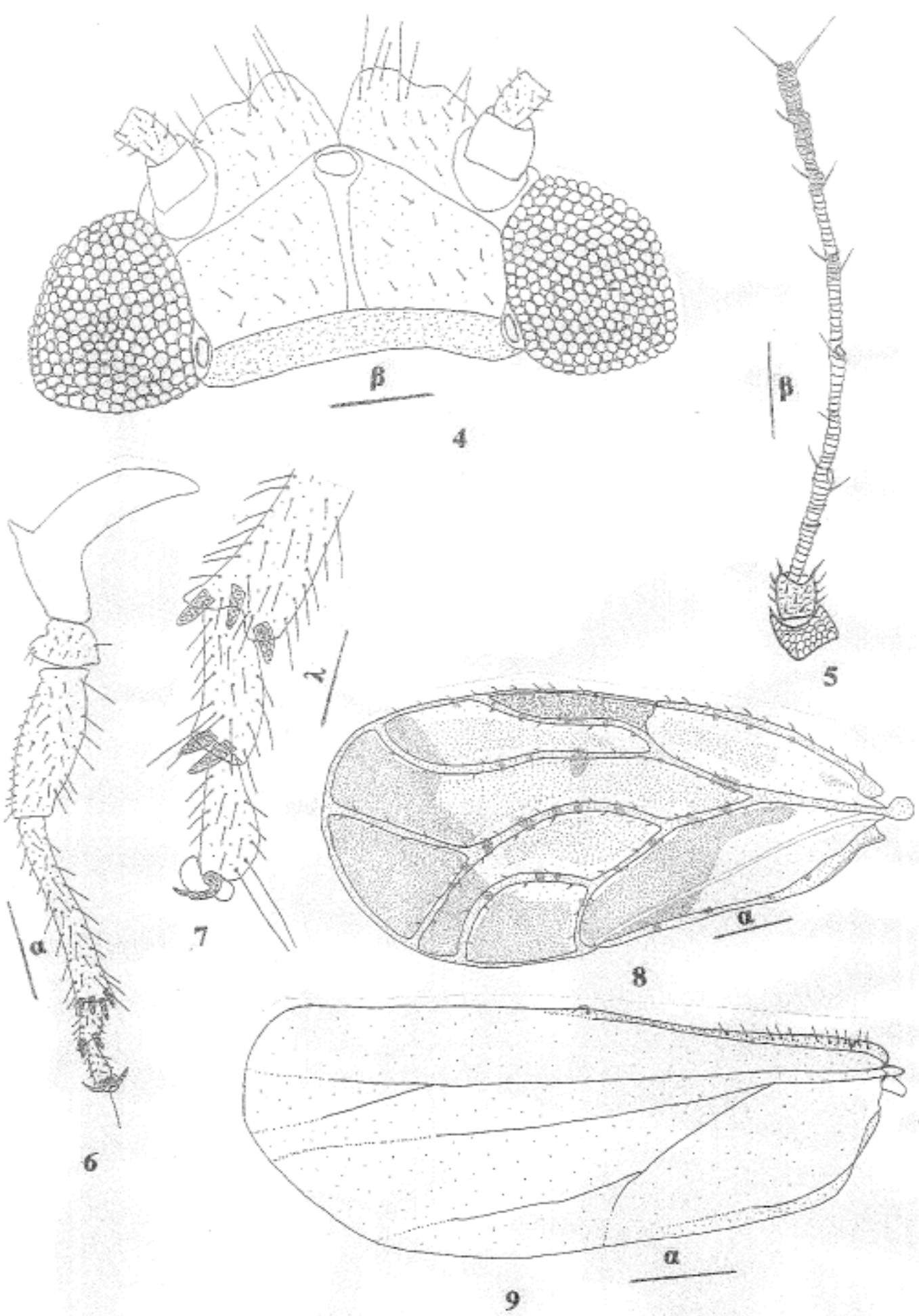

Figures 4-9: Euryconus dialia sp. nov.: 4, adult head dorsal view; 5, adult antenna; 6, 7, hind leg; 8, forewing; 9, hindwing. Scale bars: $\lambda=0.06 \mathrm{~mm} ; \alpha=0.24 \mathrm{~mm} ; \beta=0.12 \mathrm{~mm}$. 
Vol. 5, No. 04; 2020

ISSN: $2456-8643$

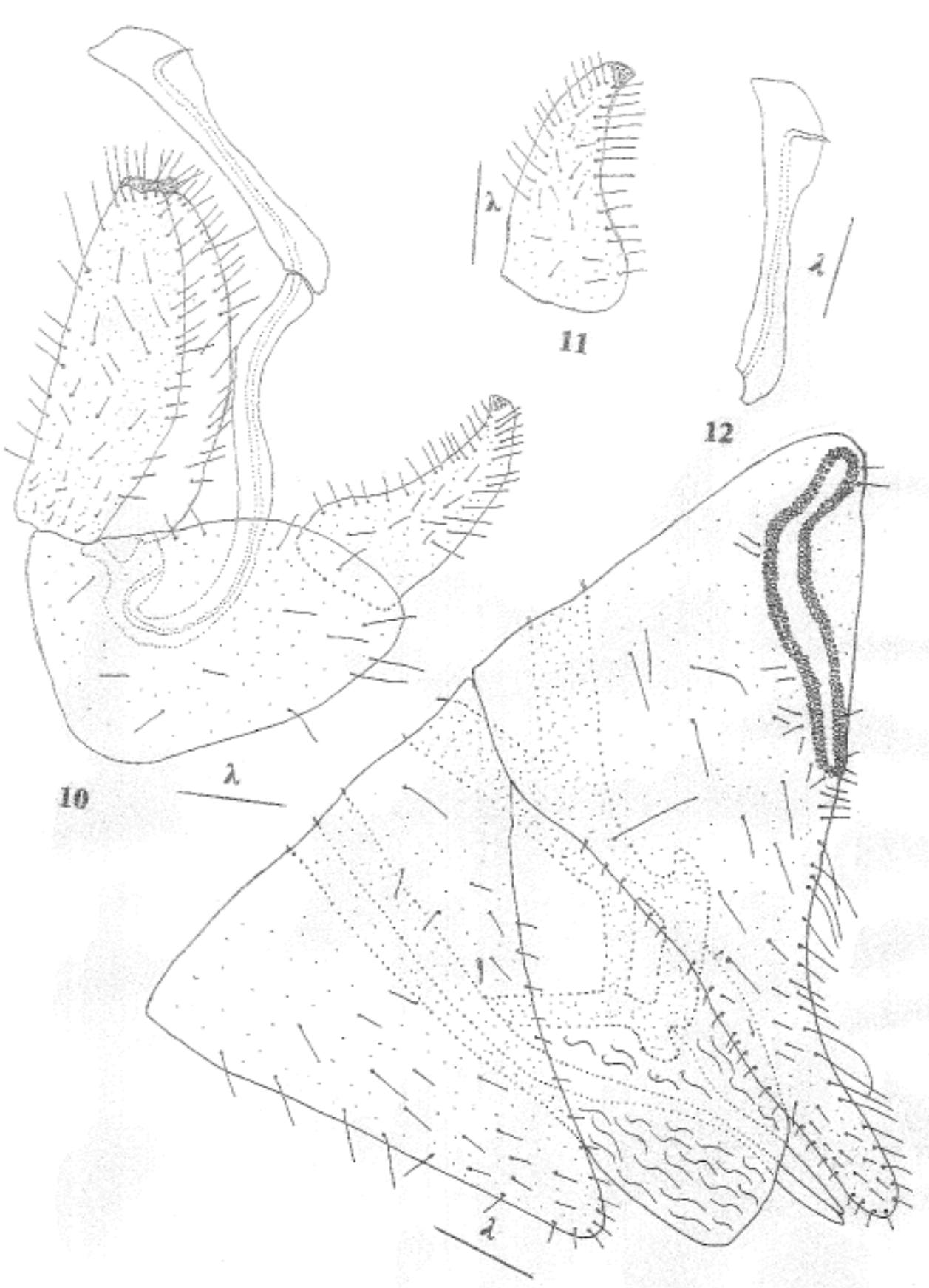

13

Figures 9-13: Euryconus dialia sp. nov : 10, male terminalia in profile; 11, paramere internal face; 12, distal segment of aedeagus; 13, female terminalia in profile. Scale bars: $\lambda=0.06 \mathrm{~mm}$. 

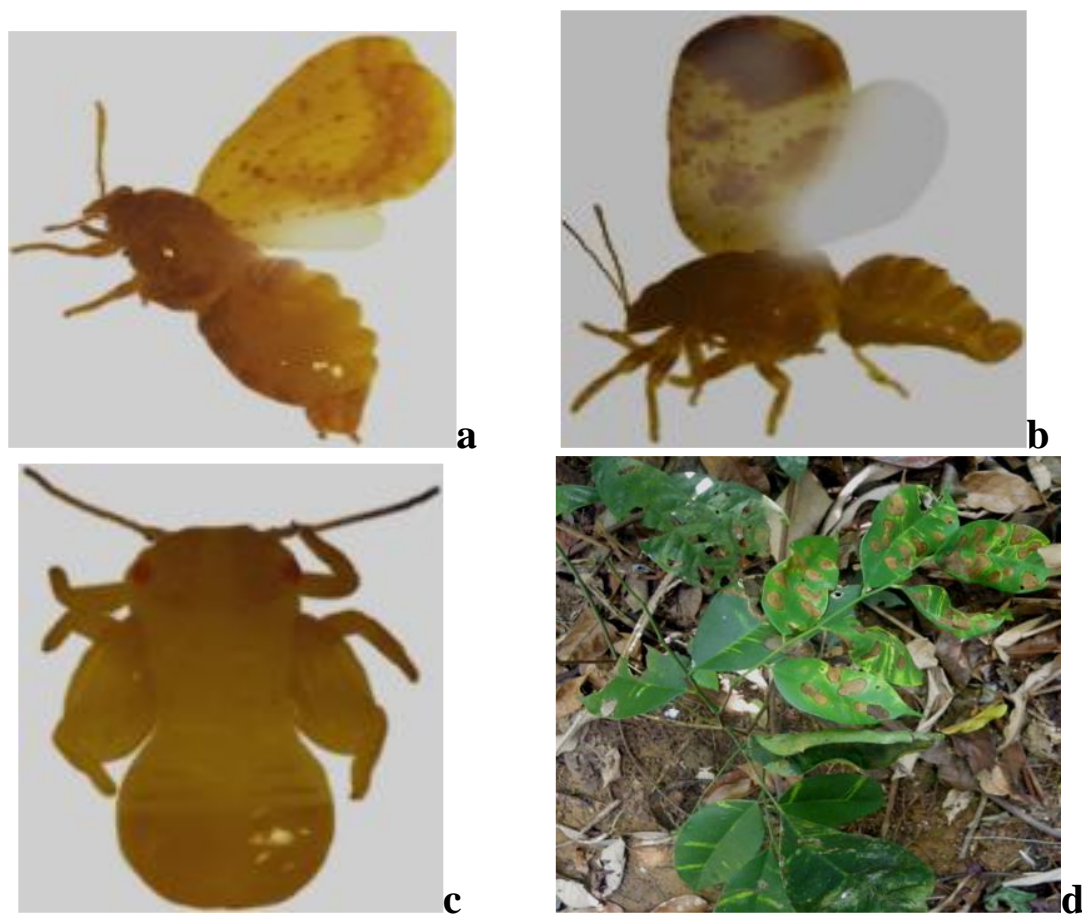

Figure 14: a, female of Euryconus dialia; b) male of Euryconus dialia; c) fifth instar immature of Euryconus dialia; d) type of demage.

Table 1: Measurements $(\mathrm{mm})$ of Eryconus dialia sp. nov. fifth intar immature $(\mathrm{N}=$ number of measured specimens)

\begin{tabular}{|llllll|}
\hline Parameters & $\mathbf{N}$ & Min & Max & Mean & S.D \\
BL & 35 & 1.20 & 1.91 & 1.56 & 0.18 \\
BW & 35 & 0.43 & 0.66 & 0.59 & 0.06 \\
AL & 35 & 0.46 & 0.63 & 0.56 & 0.03 \\
MTL & 35 & 0.23 & 0.31 & 0.25 & 0.02 \\
WL & 35 & 0.43 & 0.63 & 0.53 & 0.05 \\
\hline
\end{tabular}

Abbreviations: $\mathbf{B L}=$ body length; $\mathbf{B W}=$ body width; $\mathbf{A L}=$ antenna length; $\mathbf{W L}=$ forewing-pad length; $\mathbf{M T L}=$ metatibial length; $\mathbf{M i n}=$ minimum; $\mathbf{M a x}=$ maximum; $\mathbf{S} . \mathbf{D}=$ standard deviation. 
Table 2: Measurements (mm) of Eryconus dialia sp. nov adults $(\mathrm{N}=$ number of measured specimens)

\begin{tabular}{|lllllllllll|}
\hline & \multicolumn{4}{c}{ Males } & & \multicolumn{7}{c}{ Females } \\
parameters & N & Min & Max & Mean & S.D & N & Min & Max & Mean & S.D \\
BL & 35 & 2.11 & 3.70 & 3.27 & 0.33 & 52 & 2.94 & 4.41 & 3.95 & 0.29 \\
BW & 35 & 0.64 & 1.00 & 0.77 & 0.08 & 52 & 0.58 & 1.00 & 0.85 & 0.08 \\
HW & 35 & 0.94 & 1.17 & 1.06 & 0.07 & 52 & 1.05 & 1.29 & 1.19 & 0.06 \\
AL & 35 & 1.00 & 1.35 & 1.22 & 0.09 & 52 & 1.11 & 1.35 & 1.24 & 0.05 \\
F1L & 35 & 0.05 & 0.12 & 0.11 & 0.01 & 52 & 0.11 & 0.11 & 0.11 & 0.00 \\
GPL & 35 & 0.05 & 0.12 & 0.11 & 0.01 & 52 & 0.05 & 0.12 & 0.11 & 0.01 \\
WL & 35 & 2.17 & 2.94 & 2.65 & 0.16 & 52 & 2.82 & 3.52 & 3.15 & 0.17 \\
WW & 35 & 1.05 & 1.35 & 1.23 & 0.07 & 52 & 1.17 & 1.76 & 1.54 & 0.11 \\
wL & 35 & 1.76 & 2.70 & 2.29 & 0.20 & 52 & 2.35 & 3.23 & 2.74 & 0.17 \\
wW & 35 & 0.58 & 1.11 & 0.86 & 0.10 & 52 & 0.82 & 1.17 & 1.03 & 0.09 \\
MTL & 35 & 0.52 & 0.76 & 0.69 & 0.05 & 52 & 0.64 & 0.82 & 0.74 & 0.05 \\
MFL & 35 & 0.41 & 0.58 & 0.50 & 0.04 & 52 & 0.41 & 0.64 & 0.54 & 0.05 \\
MPL & 35 & 0.17 & 0.29 & 0.24 & 0.03 & 52 & & & & \\
PL & 35 & 0.29 & 0.41 & 0.35 & 0.37 & 52 & & & & \\
DAEL & 35 & 0.11 & 0.23 & 0.18 & 0.32 & 52 & & & & \\
FPL & & & & & & 52 & 0.47 & 0.70 & 0.61 & 0.04 \\
FSPL & & & & & & 52 & 0.35 & 0.52 & 0.42 & 0.04 \\
\hline Abbrvat & & & & & & & & & & \\
\hline
\end{tabular}

Abbreviations: $\mathbf{B L}=$ body length; $\mathbf{B W}=$ body width; $\mathbf{H W}=$ head width; $\mathbf{A L}=$ antenna length; $\mathbf{F}_{1} \mathbf{L}=$ length of first antennal flagellomere; $\mathbf{G P L}=$ frontal cone length; $\mathbf{W} \mathbf{L}=$ forewing length; $\mathbf{W W}=$ forewing width; $\mathbf{w L}=$ hindwing length; $\mathbf{w W}=$ hindwing width; $\mathbf{M T L}=$ metatibial length; $\mathbf{M F L}=$ metafemur length $\mathbf{M P L}=$ male proctiger length $\mathbf{P L}=$ paramere length $\mathbf{D A E L}=$ distal segment of aedeagus length; FPL $=$ female proctiger length; $\mathbf{F S P L}=$ female subgenital plate length : Min= minimum; $\mathbf{M a x}=$ maximum; $\mathbf{S} . \mathbf{D}=$ standard deviation.. 
Vol. 5, No. 04; 2020

ISSN: $2456-8643$

\section{REFERENCES}

[1] Hodkinson I.D., 1974. The biology of the Psylloidea (Homoptera): a review. Bulletin of Entomological Research, 64: 325-339.

[2] Burckhardt, D., 1994. Psylloid pests of temperate and subtropical crop and ornamental plants (Hemiptera, Psylloidea): a review. Trends in Agricultural Sciences, Entomology, 2, 173-186.

[3] Burckhardt D., 2005. Ehrendorferiana, a new genus of Neotropical jumping plant lice (Insecta: Hemiptera: Psylloidea) associated with conifers (Crupressaceae). Organisms Diversity \& Evolution, 5, Electr. Suppl. 12: 1-10.

[4] Hollis D., 2004. Australian Psylloidea: jumping plant-lice and lerp insects. Australia Biological Resources Study. 216 p.

[5] Hodkinson, I.D. 2009. Life cycle variation and adaptation in jumping plant lice (Insecta: Hemiptera: Psylloidea): a global synthesis. Journal of Natural History, 43, 65-179.

[6] Annecke D.P. \& Cilliers C.J. 1963. The Citrus psylla, Trioza erytreae (Del Guercio) and its parasites in South Africa. South African Journal of Agricutural Science, 6: 187-192.

[7] Catling H.D., 1973b. Results of a survey for psyllid vectors of Citrus greening disease in Réunion. FAO plant Protection Bulletin.

[8] Tamesse J.L., 1996. Ecologie de Trioza erytreae Del Guercio (Homoptera : Triozidae), vecteur de la maladie de verdissement des agrumes au Cameroun. Thèse de Doctorat de 3ème cycle, Université de Yaoundé I, 296 p.

[9] Mifsud D., \& Burckhardt D., 2002. Taxonomy and phylogeny of the Old World jumping plant-louse genus Paurocephala (Insecta, Hemiptera, Psylloidea). Journal of Natural History.36: 1887-1986.

[10] Dzokou V. J., Yana W., Soufo L. \& Tamesse J. L., 2020. Pseudoeriopsylla mpoamei sp. n., a new pest of jumping plant-louse (Hemiptera: Psylloidea: Homotomidae) from western Cameroon associated with Ficus platyphylla Del. (Moraceae). Journal of Entomology and Zoology Studies 8(2): 137-141.

[11] Dzokou V.J., Yana W., \& Tamesse J.L., 2019. Pseudoeriopsylla bitomi sp. n. (Hemiptera: Homotomidae), a new pest of Ficus platyphylla (Moraceae) from the Western Region of Cameroon. International Journal of Agriculture, Environment and Bioresearch. 4(1): 18-27.

[12] Dzokou V.J., Yana W., Tamesse J.L., \& De Coninck E. 2017. Pseudoeriopsylla etoundii sp.n., a new species of Psyllids (Hemiptera-Homotomidae), pest of Ficus leprieuri (Moraceae) from West-Cameroon. Int. J. Biol. Chem. Sci. 11(4): 1592-1600.

[13] Dzokou V.J., Tamesse J.L. \& Burckhardt D., 2009. Trioza messii sp.n., a new species of jumping plant-louse (Hemiptera: Triozidae) from Cameroon associated with Caloncoba welwitschii (Oliv.) Gilg. (Flacourtiaceae). Cameroon Journal of Experimental Biology, vol. 05 (1): 29-36.

[14] Tamesse J.L. \& Dayang L.D., 2018. Newly Described Psyllid Diclidophlebia andjigae sp.n. (Hemiptera:Liviidae), on Grewia venusta (Tiliaceae) from Cameroon. Journal of Entomology. 15(1): 19-27.

[15] Yana W., Dzokou V. J., Mveyo Ndankeu Y. P., Douni Goune V. S., \& Tamesse J. L., 2019b. Trioza schefflerae sp. nov. (Hemiptera: Triozidae), a new species of psyllid associated with Schefflera abyssinica (Araliaceae) from Cameroon. International Journal of Agriculture, Environment and Bioresearch; 4(6): 218-228. 
[16] Yana W., Dzokou V.J., Ndankeu Mveyo Y.P. \& Tamesse J.L.,2019a. Two species of psyllids genus Paurocephala (Hemiptera: Psyllidae) pest insects associated to Connaraceae in Cameroon. International Journal of Entomology Research; 4 (2): 13-19.

[17] Yana W., Mveyo Ndankeu Y.P., Dzokou V.J. \& Tamesse J.L.,2017. Trioza kala sp.n. (Hemiptera: Triozidae), a new species of psyllid associated with Beilschmiedia obscura (Fouilloy et al. 1974) (Lauraceae) from Cameroon. Journal of Entomology and Zoology Studies. 2017; 5(6): 2179-2183.

[18] Yana W., Ndankeu Mveyo Y.P., Dzokou V.J. \& Tamesse J.L. 2015. Jumping plant lice of the family Carsidaridae (Hemiptera: Psyloidea) taxonomic, faunistic; phenology and host plants. I. Bio. And Env. Sci. 6(6): 1-20.

[19] Tamesse J.L., Mapon I.N. \& Yana W., 2014. Pseudophacopteron burckhardti sp.n. (Hemiptera: Phacopteronidae), new species of psyllid associated with Zanthozylon gilletii (Rutaceae) from Cameroon. Journal of Entomology. 11(3): 176-181.

[20] Tamesse J.L., Dzokou V.J. \& Yana W., 2011. Phytolyma tchuentei sp.n. (Hemiptera: Homotomidae), a new species of psyllid associated with Morus mesozygia (Moraceae) from Cameroon. Entomological Research. 41: 174-177.

[21] Tamesse J.L., Soufo L., Yana W., \& Dzokou V.J., 2010. First record of Blastopsylla occidentalis Taylor, 1985 (Hemiptera: Psyllidae), a Eucalyptus psyllid in Cameroon, Central Africa. Entomological Research. 40: 211-216.

[22] Malenovský I., Burckhardt D. \& Tamesse J.L., 2007. Jumping plant-lice of the family Phacopteronidae (Hemiptera: Psylloidea) from Cameroon. Journal of Natural History, 41 (2932): 1875-1927.

[23] Burckhardt D., Aléné D.C., Ouvrard D., Tamesse J.L. \& Messi J., 2006a. Afrotropical members of the jumping plant-louse genus Diclidophlebia (Hemiptera: Psylloidea). Invertebrate Systematics, 20: 367-393.

[24] Hollis, D. 1984. Afrotropical jumping plant lice of the family Triozidae (Homoptera: Psylloidea). Bulletin of the British Museum (Natural History) Entomology, 49, 1-102.

[25] Burckhardt D. \& Queiroz D.L., 2020. Neotropical jumping plant-lice (Hemiptera, Psylloidea) associated with plants of the tribe Detarieae (Leguminosae, Detarioideae). Zootaxa, 4733 (1): 001-073.

[26] Capener, A.L., 1973. Southern African Psyllidae (Homoptera)-3. A new genus and new species of South African Psyllidae. Journal of the Entomological Society of Southern Africa, 36, $37-61$.

[27] Burckhardt D., \& Mifsud D., 1998. Psylloidea (Insecta: Hemiptera) of Arabian Peninsula. Fauna of Arabia, 17: 7-49.

[28] Burckhardt D. \& Ouvrard D., 2012. A revised classification of the jumping plant-lice (Hemiptera: Psylloidea). Zootaxa, 3509 (1):1-34.

[29] Heslop-Harrison, G. 1961. The Arytainini of the subfamily Psyllinae, HemipteraHomoptera, family Psyllidae.-II. Annals and Magazine of Natural History, 13, 417-439.

[30] Li, F. 2002. Homoptera: Psylloidea. In: F.-s. Huang, H. Yin, R. Zeng, M. Lin \& M. Gu (Eds), Forest insects of Hainan. Science Press, 1064 pp., Beijing, pp. 171-189.

[31] Li, F. 2004. Homoptera: Psylloidea: Phacopteronidae, Aphalaridae, Calophyidae, Psyllidae and Triozidae. In: X.-K. Yang (Ed), Insects from Mt. Shiwandashan Area of Guangxi. China Forestry Publishing House, Beijing (China), pp. 213-226. 
[32] Schwarz, E.A. 1904. Notes on North American Psyllidae. Proceedings of the Entomological Society of Washington, 6, 234-245.

[33] Aulmann, G., 1912b. Beiträge zur Kenntnis der Psylliden-Fauna von Neu-Guinea. Entomologische Rundschau, 29, 117-118.

[34] Vondráček, K. 1963. Jumping plant-lice (Psylloidea - Homoptera) of Central Africa. Part I (Congo). Acta Entomologica Musei Nationalis Pragae, 35, 263-290.

[35] Yang, C.T. 1984. Psyllidae of Taiwan (Taiwan Museum Special Publication Series 3), 305 pp.

[36] Li, F. 2005. Homoptera: Psylloidea. In: X.-K. Yang (Ed), Insects Fauna of Middle-West Qinling Range and South Mountains of Gansu Province. Science Press, Beijing (China), pp. 142-213.

[37] Li, F., Cui, J.-X. \& Cai, W.-Z. 2006. Pugionipsylla, a new jumping plant lice genus (Hemiptera: Psylloidea: Psyllidae) from China. Oriental Insects, 40, 195-200.

[38] Pettey, F.W. 1925. New South African Psyllids. South African Journal of Natural History, 5, $125-142$.

[39] Fang, S.J. \& Yang, C.T. 1986. Psylloidea of Taiwan (Homoptera: Sternorrhyncha) Supplement. Monograph of Taiwan Museum, 6, 119-176.

[40] Burckhardt, D. \& Queiroz, D.L. (2012) Commented checklist of the jumping plant-lice (Hemiptera: Psylloidea) from Brazil. Zootaxa, 3571 (1), 26-48. 